\title{
Development and Validation of Muslim Moral Emotions Inventory (MMEI)
}

Rezki Perdani Sawai, Sidek Mohd Noah, Abdul Rashid Abdul Aziz, Joki Perdani Sawai, Roslee Ahmad

To Link this Article: http://dx.doi.org/10.6007/IJARBSS/v11-i10/11502

DOI:10.6007/IJARBSS/v11-i10/11502

Received: 03 August 2021, Revised: 26 August 2021, Accepted: 19 September 2021

Published Online: 16 October 2021

In-Text Citation: (Sawai et al., 2021)

To Cite this Article: Sawai, R. P., Noah, S. M., Aziz, A. R. A., Sawai, J. P., \& Ahmad, R. (2021). Development and Validation of Muslim Moral Emotions Inventory (MMEI). International Journal of Academic Research in Business and Social Sciences, 11(10), 1264-1276.

Copyright: (C) 2021 The Author(s)

Published by Human Resource Management Academic Research Society (www.hrmars.com)

This article is published under the Creative Commons Attribution (CC BY 4.0) license. Anyone may reproduce, distribute, translate and create derivative works of this article (for both commercial and non-commercial purposes), subject to full attribution to the original publication and authors. The full terms of this license may be seen at: http://creativecommons.org/licences/by/4.0/legalcode

Vol. 11, No. 10, 2021, Pg. 1264 - 1276

Full Terms \& Conditions of access and use can be found at http://hrmars.com/index.php/pages/detail/publication-ethics 


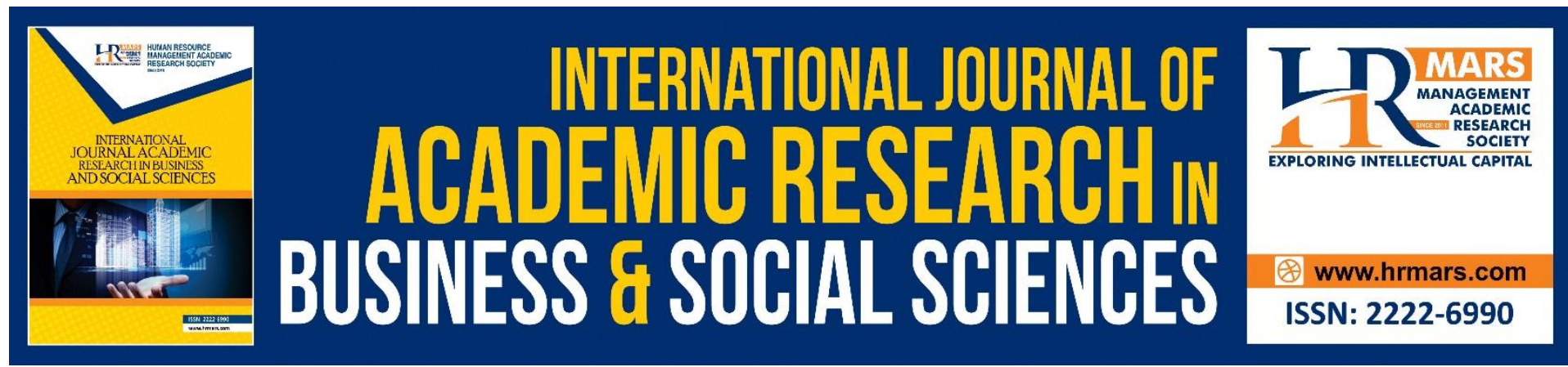

\title{
Development and Validation of Muslim Moral Emotions Inventory (MMEI)
}

\author{
Rezki Perdani Sawai ${ }^{1}$, Sidek Mohd Noah², Abdul Rashid Abdul \\ Aziz ${ }^{3}$, Joki Perdani Sawai ${ }^{4}$, Roslee Ahmad ${ }^{5}$ \\ 1,3,5 Faculty of Leadership and Management, Universiti Sains Islam Malaysia (USIM), Bandar \\ Baru Nilai, 71800 Nilai, Negeri Sembilan, Malaysia, ${ }^{2}$ Faculty of Educational Studies, Universiti \\ Putra Malaysia (UPM), Putra Infoport, 43400 Serdang, Selangor, Malaysia, ${ }^{4}$ Faculty \\ Education \& Psychology, Universiti Malaysia Sabah (UMS), 88400 Kota Kinabalu, Sabah, \\ Malaysia. \\ Email: rashid@usim.edu.my
}

\begin{abstract}
The increased number of criminal offenses statistics among adolescents in Malaysia is alarming. This is believed to be rooted from the reduce of moral emotions such as shame and guilt in themselves. Therefore, this study presents the results of an exploratory factor analysis of the Muslim Moral Emotions Inventory (MMEI), a self-report measure of moral emotions of shame and guilt to overcome this issue. This instrument was administered to a sample of Malaysian-Muslims youth $(n=640)$ to determine the factor structure and internal reliability of these scales. The analysis showed that 18 items factored around four factors of perceived Guilt subscales includes God consciousness, Care for Others, Fear of Punishment and Forgiveness. Another 18 items factored around five factors of perceived Shame subscales include Positive Speech, Sensitive Towards Others Judgment, Safeguarding Chastity, Guarding One's View and Modest Self-presentation. The Shame scale accounted for $54.48 \%$ of $\backslash$ the variance, while the Guilt scale accounted for $56.10 \%$ of the variance. The results of showed that the factor structure of the two moral emotions scales of the MMEI was significantly measured with the current sample of Muslims youth. Cronbach alpha, split-half coefficients and item analysis verified the reliability of instrument. The significance of adaptive shame and guilt as a unique contributor to psychological well-being and applications for the MMEI in assessment and outcome research among youth are discussed.
\end{abstract}

Keywords: Shame, Guilt, Exploratory Factor Analysis

\section{Introduction}

Recently, there is an increase interest among social psychologists to study the role of moral emotions (shame and guilt) in determining moral behaviour. Most of the prominent scholars in the field such as Haidt (2003); Tangney and Stuewig (2011) believed that shame and guilt can be a driving force to steer an individual toward prosocial behaviour and away from negative ones. Shame and guilt are secondary emotions that requires awareness of self, understanding and evaluation of people about themselves and their own behaviour in 
relation to normative standards, rules and social objectives, which involve complex cognitive processes.

The hot debate among psychologists regarding shame and guilt is whether shame and guilt can be considered as adaptive and/or maladaptive emotions which can contribute to the development of social, moral and also psychological well-being. The social-adaptive perspective proposes that guilt is an inherently adaptive emotion and shame is an inherently maladaptive emotion (Dempsey, 2017). Based on this perspective, those interested in moral character development and psychopathology should work to increase an individual's guiltproneness and decrease an individual's shame-proneness.

The most widely used instrument to measure shame and guilt known as Test of SelfConscious Affect (TOSCA) was developed within the social-adaptive framework. This instrument was developed by Tangney, Wagner, \& Gramzow in 1989. TOSCA-shame has been shown to be related to depression, anxiety, social anxiety, self-derogation, eating disorders, posttraumatic stress disorder, anger, aggression, alcohol and drug problems (including early drinking), decreased self-forgiveness, and low self-esteem. Meanwhile, TOSCA-guilt has been shown to be unrelated to anger, state anxiety, phobic anxiety, depression, interpersonal sensitivity, self-esteem, suicide ideation, negative self-evaluation, externalizing, and social insecurity. Many researchers have criticized TOSCA because of it biasness toward guilt as an adaptive emotion (Ferguson et al., 2000; Scheff, 2014).

On the other hand, the functionalist perspective, argues that both guilt and shame can serve as adaptive or maladaptive forces depending on the situational appropriateness, duration, intensity, and so forth (Dempsey, 2017). It emphasizes on when do guilt and shame serve adaptive and maladaptive purposes. Guilt can also be seen as maladaptive when people develop an excessive or distorted sense of responsibility (Tangney, Stuewig \& Mashek, 2007). Aknouche and Noor found that there is an adaptive type of shame as induced by the religion of Islam. They suggested future research on the role of instilling adaptive shame, specifically in Muslim societies. The conclusions made regarding shame as a maladaptive emotion could exist because of biases in how shame and guilt are defined, operationalized, and measured by the TOSCA (Dempsey, 2017). To address this issue, the current study employed the conceptualization of shame and guilt from an Islamic perspective, taking into account the functionalist perspective.

An observed gap in the current literature on measures of shame and guilt, particularly for religious populations and societies is the psycho-spiritual dimension. Jumahat, \& Abdullah (2014); Othman (2011) encouraged Muslim scholars, in particular, to develop psychometric instruments that are more relevant and suited to the need of Muslim populations grounded in the values of source texts of Islam, the Quran and Sunnah. The need of psychometric instruments that suited Muslims population is more prominent in Malaysia in view of increasing numbers of criminal offenses statistics involving Malay children and adolescents as mentioned in Malaysia Crime Statistics Report (2020). The criminal offenses were those related to theft, injuring people, burglary, rape and robbery. Tibbetts (1997) and Rahman et al. (2011) revealed that the increase in criminal offenses cases is believed to be rooted from the reduce of moral emotions such as shame and guilt. Thus, this research aimed at developing an Islamic measure for shame and guilt, known as the Muslim Moral Emotions Inventory (MMEI). The validity of the Muslim Moral Emotions Inventory was initially assessed 
through Exploratory Factor Analysis. The study sets out to answer the following research questions: (i) what are the underlying factors of shame and guilt scales? (ii) how many factors explain the concept of shame and guilt? and (iii) what is the total proportions of variance explaining shame and guilt?

\section{Methodology \\ Pilot Testing}

Pilot testing of the Muslim Moral Emotions Inventory was conducted with 133 respondents. All of the respondents came from three institutions, namely, Tahfiz, Public Institutions of Higher Learning (IPTA/IPTS) and Rehabilitation Centers in Negeri Sembilan and Selangor, Malaysia. The instrument consisted of 135 item statements. Descriptive analysis of the respondents reported that there are 34 male respondents which constitute $25.6 \%$ from total sample and the rest (99) are the female students which accounts for the majority of the respondents (74.4\%). The respondents' age is between $18-25$ years old. Percentage of those who are 21 years old is higher compared to other ages $(N=44 ; 33.1 \%)$. Reliability analysis using the Cronbach's Alpha test revealed these results. The results of Cronbach's alpha reliability of Shame and Guilt scale are shown in Table I and II.

Table I: Reliability Value for Shame Scale

\begin{tabular}{|l|l|l|}
\hline Subconstructs & Alpha value & Number of items \\
\hline Positive Speech One's & 0.877 & 15 \\
\hline Modest Self-presentation & 0.831 & 15 \\
\hline $\begin{array}{l}\text { Safeguarding } \\
\text { Chastity }\end{array}$ & 15 \\
\hline Lowering one's Gaze & 0.756 & 15 \\
\hline $\begin{array}{l}\text { Concern with others' } \\
\text { Judgment }\end{array}$ & 0.772 & 15 \\
\hline
\end{tabular}

Total reliability values $\mathbf{~} 0.95$ (75 items)

Table II: Reliability Value for Guilt Scale

\begin{tabular}{|l|l|l|}
\hline Subconstructs & Alpha value & Number of items \\
\hline Care for others & 0.652 & 15 \\
\hline Fear of punishment & 0.857 & 15 \\
\hline God consciouness & 0.640 & 15 \\
\hline Forgiveness & 0.798 & 15 \\
\hline
\end{tabular}

Total reliability values $\mathbf{~} \mathbf{0 . 8 8 1}$ (60 items)

The reliability value of alpha coefficient that is said to be good or acceptable as reliable is varied. According to Konting (2000), the reliability coefficient of 0.60 or more is acceptable. Mohamad (2001) recommends that the value between 0.65 and 0.85 is good and acceptable. The relatively high value is placed by Hopkins (1998) which is 0.90 minimum to say the item has good reliability. However, most researchers suggest that the value of alpha coefficient greater than 0.8 typically indicates the high level of reliability and acceptability of an instrument (Aiken 2000; Cohen et al., 2000). Based on Table I and II, the values range between .756 to .831 for Shame Scale, while for Guilt Scale the values are between .640 to .652. The obtained result indicated the internal consistency of scores for the instrument. 


\section{Procedures}

In order to conduct exploratory factor analysis, Hatcher (1994) recommended a ratio of a minimum of 5 cases for each item in a questionnaire. Since this study have 90 items, multiply by 5 cases, the total comes up to 450 . Thus, the minimum samples required to conduct EFA for the items in the instruments for this study was 450 . The main study involved a total of 640 respondents from three institutions, namely, Tahfiz, Public Institutions of Higher Learning (IPTA/IPTS) and Rehabilitation Centers in Klang Valley, Malaysia. Respondents were between 18-25 years old of age ( $M$ age=20.17, SD=1.84). Descriptive analysis reported that there were 271 male respondents which constituted $42.3 \%$ of the total sample and 369 females accounting $57.7 \%$. Using PCA, the sample size depends on the number of items in the instrument. The minimum size is determined by the rule of thumb that there should be at least five times as many cases as there are variables to be analyzed (Hair et al., 2006).

\section{Instrumentation}

The survey instrument used in the study to measure shame and guilt- the Muslim Moral Emotions Inventory- developed by the first author based on the Quran, Sunnah and the works of several prominent Muslim scholars. The final instrument after pilot testing consisted of 90 items; 50 items to measure shame and 40 items to measure guilt. The MMEI examines individuals' perception towards shame and guilt using a 10-point Likert scale, ranging from 0 (Does not describe me at all) to 10 (Definitely describe me). Example items are, "Dress to cover my aurat/body", "Am careful about how I behave so that will not be looked down upon by others", "Saying offensive words" (negative item), "Do not care about how people respond to me" (negative item). For the second dimension, Guilt, there are 40 items using a ten-point scale ranging from (0) Does not describe me at all" to (10) "Definitely describe me," to measure a respondents' perception of forgiveness, fear of punishment, God consciousness and care for others/empathy. Example items include, "Never lose hope in Allah's forgiveness" and "Accept the punishment for what I did wrong". Internal consistencies was found to be acceptable (.83 for guilt scale and .82 for shame scale).

\section{Data Analysis}

The data were analyzed using PCA to identify the underlying dimensions for each construct of the instrument. The reliability of each construct was based on Cronbach's Alpha. coefficient alpha was used.

\section{Result}

Exploratory factor analysis was run separately for each scale. To determine the number of factors to retain, 4 criteria were used:

1. The presence of correlation with the other resulting factors (Barlett's test, KMO of MSA)

2. Factors with eigenvalues much greater than 1.0.

3. The value of factor loading for each variable was greater than 0.40 .

4. Surpress small coefficient values below than 0.50 .

\section{Shame Construct}

In order to justify the use of principle component analysis, one of the important assumptions to be assessed is the intercorrelations among the items. Barlett Sphericity Test was statistically significant, $\chi 2(276)=4897.39, p=.001$ the variables were highly correlated to one another. The measurement of sampling adequacy (MSA) for each item showed that all 
of the values were greater than .80. The Kaiser-Meyer- Olkin Measure of Sampling Adequacy was .857. Thus, there was evidence for the overall measurement of sampling adequacy fulfilling the requirement of at least .50 (18). Moreover, EFA showed that there were 5 factors generated by the data with eigenvalues greater than 1.0, accounting for $54.88 \%$. of the total variance described (Table III). This indicates that five underlying dimensions explained more than $50 \%$ of the variance among the 50 variables.

Table III: Rotated Component Matrix

\begin{tabular}{|c|c|c|c|c|c|}
\hline \multicolumn{6}{|l|}{ Component } \\
\hline & $\begin{array}{l}\text { Positive } \\
\text { Speech }\end{array}$ & $\begin{array}{l}\text { Sensitive to } \\
\text { Others } \\
\text { Judgment }\end{array}$ & $\begin{array}{l}\text { Guarding } \\
\text { One's View }\end{array}$ & $\begin{array}{l}\text { Safeguarding } \\
\text { Dignity }\end{array}$ & $\begin{array}{l}\text { Modest Self- } \\
\text { Presentation }\end{array}$ \\
\hline $\mathrm{SH} 20$ & & & .780 & & \\
\hline $\mathrm{SH} 21$ & & & .779 & & \\
\hline $\mathrm{SH} 29$ & & & .568 & & \\
\hline SH50 & & & .623 & & \\
\hline $\mathrm{SH} 12$ & & & & & .743 \\
\hline $\begin{array}{l}\mathrm{SH} 13 \\
\text { SH9 }\end{array}$ & & & & & $\begin{array}{l}.810 \\
.526\end{array}$ \\
\hline $\mathrm{SH} 44$ & & & & .606 & \\
\hline $\mathrm{SH} 45$ & & & & .841 & \\
\hline $\mathrm{SH} 46$ & & & & .827 & \\
\hline $\mathrm{SH} 49$ & & & & .586 & \\
\hline SH14 & .658 & & & & \\
\hline SH16 & .521 & & & & \\
\hline $\mathrm{SH} 30$ & .744 & & & & \\
\hline SH33 & .747 & & & & \\
\hline $\mathrm{SH} 35$ & .771 & & & & \\
\hline $\mathrm{SH} 36$ & .750 & & & & \\
\hline $\mathrm{SH} 48$ & .704 & & & & \\
\hline SH15 & & .529 & & & \\
\hline $\mathrm{SH} 25$ & & .716 & & & \\
\hline $\mathrm{SH} 26$ & & .688 & & & \\
\hline $\mathrm{SH} 28$ & & .679 & & & \\
\hline $\mathrm{SH} 38$ & & .657 & & & \\
\hline $\mathrm{SH} 40$ & & .556 & & & \\
\hline Eigenvalue & 3.718 & 2.834 & 2.440 & 2.327 & 1.759 \\
\hline \% Variance & 15.490 & 27.299 & 37.464 & 47.158 & 54.488 \\
\hline
\end{tabular}

Factor 1 consisted of 7 items. Based on the contents of the items (Table III), factor 1 was labelled as Positive Speech. The main purpose of the items in this factor is to measure the individual an individual's ways of speaking according to Al-Quran and As-Sunnah. Those who has high shame will tend to safeguard his tongue from any negative speech. Guarding 
one's tongue from speaking in an offensive or rude manner, speaking about issues that are of no concern to that individual. The religion of Islam plays a significant role in shaping the way Muslim should communicate or "rules of speaking". People who do not speak politely, will be considered rude. Meanwhile, people who speak politely will be generally get praise and accepted by others.

Factor 2 was labelled Concern with others' judgment which consist of 6 items. This group of items measured how much individual are aware and sensitive towards others' judgment of his behaviour. The person will feel uncomfortable if others look at them negatively and try to maintain the behaviour according to the Islamic principles and societal norms. The items also indicate that shame towards other fellow beings is an essential characteristic that keeps people from harming one another and from performing indecent acts. For example, an adolescent who has shame will be careful to do anything that makes his/her parents shameful.

Factor 3 was labelled Safeguarding one's view. It consists of 4 items. The items in this factor were meant to assess whether individual Muslims safeguard their eyes from watching or looking at things that are forbidden by Islam. The items related to guarding one's view imply the need for holding one's gaze from looking at forbidden things based on the Islamic principles. The man is responsible for everything he was gifted with. He has to use whatever given by Allah SWT properly. This is true as In Surah Al-Isra', Verse 36, "And do not follow that of which you have no knowledge, Verily! The hearing, the vision and the heart; and each of those man will be questioned about them (by Allah SWT)".

Factor 4 was labelled Safeguarding one's chastity. It consisted of 4 items. This group of items measured individual activities related to the protection of progeny, which includes the protection of offspring and the reproductive system. According to Islamic teaching, those who have high shame will protect their chastity in order to maintain their dignity and avoid themselves from indulging in an indecent behavior in public and seclusion. Both are contrary to the principle of the protection of human dignity and the act of adultery and extramarital pregnancy clearly an act that can damage the purity of lineage in Islam.

Finally factor 5 consisted of 3 items. It was labelled Modest Self-presentation. The items were meant to assess the individual way of dressing. According to mainstream or orthodox Islamic teachings, Muslims are encouraged to dress in a modest fashion. Modesty in dress means a type of body concealment concerning the erogenous zones (zones of the body with sexual significance), which are context and culture dependent. Immodest reveals parts of the body that are considered "inappropriate" or imbued with sexual significance depending upon the cultural context (Henkins, 2003). The cultural context here refers to the Islamic code of dress which requires individual to dress by covering their awrah.

The finding suggests that there are five underlying dimensions of MMEl's shame construct. The dimensions are positive speech, sensitive to others' judgment, guarding one's view, safeguarding one's chastity/dignity and dress modestly. 


\section{Guilt Construct}

In order to justify the use of principle component analysis, one of the important assumptions to be assessed is the intercorrelations among the items. Barlett Sphericity Test was statistically significant, $\chi 2(210)=5265.85, p=.001$ the variables were highly correlated to one another. The measurement of sampling adequacy (MSA) for each item showed that all of the values were greater than .80. Kaiser-Meyer- Olkin Measure of Sampling Adequacy was .894. Thus, there was evidence for the overall measurement of sampling adequacy fulfilling the requirement of at least .50 (Hassan \& Bakar, 2009).

Beginning with 40 items, a varimax rotation was conducted, resulting in four factor solutions with eigenvalues greater than 1 . The result showed four factors were extracted with $56.10 \%$ of total variance explained in Table IV. This indicates that five underlying dimensions explain more than $60 \%$ of the variance among the 19 variables. Based on the contents of the items (Table IV), the factors were labelled accordingly.

Factor 1 was labelled Fear of Punishments which consist of 5 items. Guilt results from the violation of internalized moral norms and would create the expectation of punishment. This factor was meant to assess individual deeds that indicate awareness in fulfilling responsibilities as khalifah of Allah in forbidding evil characterised by the fear of Allah SWT and His punishment, desires His Paradise and wishes to attain His good pleasure. This fear will deter him from committing any vices and deter him from disobeying Allah SWT.

Factor 2 was labelled Care for Others. Factor 2 consisted of 7 items. This factor aimed to measure an understanding and internalization of responsibilities and leads to maintenance of harmonious relationship toward the Creator and other human beings, including parents, friends and neighbours. Islam emphasizes the maintenance of harmonious relationship between fellow being.

Factor 3 was labelled God Consciousness which consist of 4 items. The group of items that belongs to this factor indicates the internalization of the concept of Ihsan. Ihsan is to adore Allah as though thou do see Him for even if thou do not see Him, He nonetheless sees thee. Guilt or al-Nadam, signifies one's guilt over wrongdoing and righteous indignation at moral transgression (such as Qur'an 4:17, "Allah SWT accept the repentance of those who do evil in ignorance and repent soon afterward; to them will Allah SWT turn in mercy"). The nature and intensity of guilt are thus represented by one's conscience, which, in turn, is governed by one's moral values (Syed and Ali, 2006).

Factor 4 was labelled as Forgiveness which consists of 3 items. This factor was meant to assess the willingness of an individual to apologize and asking for forgiveness not only to the fellow being but which might also be extended to Allah SWT reflected through repentance (Tawbah). In Islam, able to forgive the mistakes of others is one of the characteristics of the righteous (Muttaqin). A person, however, cannot use their nature as an excuse to cover up his or her mistakes. Guilt motivates one to seek redemption, or it can leave one feeling hopeless. Guilt (nadam) is the sign of repentance. There is a difference between positive and negative guilt. Positive guilt leads one to remorse, seeks others and God's forgiveness. While negative guilt leads to more destructive and sinister feelings and distances one from God. The Islamic psychology of personality nurtures a healthy sense of guilt, and not a pathological guilt 
that hinders spiritual development (Thorndike, 1997). The results of the final factor solution are illustrated in Table IV.

Table IV: Rotated Component Matrix

\begin{tabular}{|c|c|c|c|c|}
\hline \multicolumn{5}{|l|}{ Component } \\
\hline & $\begin{array}{l}\text { Fear of } \\
\text { Punishments }\end{array}$ & Care for Others & $\begin{array}{l}\text { God } \\
\text { Consciousness }\end{array}$ & Forgiveness \\
\hline GU3 & .743 & & & \\
\hline GU7 & .784 & & & \\
\hline GU12 & .706 & & & \\
\hline GU14 & .505 & & & \\
\hline GU4 & .833 & & & \\
\hline GU5 & & .601 & & \\
\hline GU13 & & .671 & & \\
\hline GU15 & & .656 & & \\
\hline GU18 & & .528 & & \\
\hline GU28 & & .724 & & \\
\hline GU30 & & .679 & & \\
\hline GU40 & & .546 & & \\
\hline GU1 & & & & .758 \\
\hline GU2 & & & & .824 \\
\hline GU38 & & & & .578 \\
\hline \multicolumn{5}{|l|}{ GU11 } \\
\hline \multicolumn{5}{|l|}{ GU34 } \\
\hline GU19 & & & .635 & \\
\hline GU23 & & & .750 & \\
\hline GU24 & & & .725 & \\
\hline GU39 & & & .693 & \\
\hline Eiganvalue & 3.451 & 3.182 & 2.834 & 2.314 \\
\hline$\%$ Variance & 16.433 & 31.586 & 45.083 & 56.103 \\
\hline
\end{tabular}

Note: $\mathbf{N}=640$. Principal Component Analysis. Varimax Rotation with Kaiser Normalization

The finding suggests that there are four underlying dimensions of MMEl's guilt construct. The dimensions are fear of punishment, care for others, God consciousness, and forgiveness.

\section{Discussion}

Prior to the construction of the Muslim Moral Emotions Inventory, EFA was used to assess the strength of the relationships between variables, to identify the number of factors present in the data and to identify items that didnot load any factors or that were loaded on more than one factor. The results of EFA revealed the existence of several factors or dimensions generated from each construct of the developed instrument. The result suggests that there are five underlying dimensions of shame construct among Muslim youth. The dimensions are positive speech, sensitive towards others' judgment, guarding one's view, safeguarding one's chastity/dignity and dress modestly. The second construct, Guilt 
represented by 4 underlying subconstructs, namely, fear of puishment, care for others, God consciousness and forgiveness.

MMEl is somehow reflect the use of the functionalist approach as it takes into account the moral emotions of shame and guilt as a highly functional value. Shame does not necessarily be considered as maladaptive emotions as what has been suggested by TOSCA. Both guilt and shame can be adaptive and/or maladaptive depending on the individul's evaluation of the situation. Shame is essential to moral life by feeling flawed or defective against the moral transgression did by the person, shame act as a meant to help the person to learn from his/her own mistakes. It is also true for guilt. Both of these emotional reactions would likely promote higher efforts to avoid doing the same mistakes in the upcoming situations. Thus, to fit in the society one's need to take into account twhat is considered good by a society and the religious teaching.

The quality of a Muslim is not only measured through performing all the religious rituals but also through the social deeds (Herijanto, 2017). The social deed emphasizes on the priciple of Amar Ma'ruf Nahi Munkar, or commanding the good and forbidding the evil. Others'gaze or known as social signal will prompt toward shame. Islam also recognizes the signaling function of moral emotions which is imprinted in human nature. Moral emotions work in a way that they gives a signal whenever the individual's behavior is diapprove by the other persons as it create uncomfortable feeling in the heart. However, if the feeling of guilt is overwhelmed, a person can feel hopeless which can leads to suicidality. This comes from the belief that one's sin is too big to be forgiven in addition to lower self-esteems and greater anxiety (Liu, 2015). Thus guilt can actually motivate an individual to seek redemption or it can leave one feeling hopeless and depress. In the light of the above discussion, shame should not be regarded as totally maladaptive while guilt as totally adaptive. Based on the Quran and Sunnah, both can be adaptive and maladaptive. This Islamic understanding of shame and guilt is significant in uncovering the other "face" of shame and guilt.

\section{Conclusion}

In conclusion, the study suggests that there are five underlying dimensions of shame construct among Youth from three different institution in Malaysia. The dimensions are positive speech, guarding one's view, sensitive towards others judgment and modest selfpresentation. While, for the guilt construct, the study reveals that there are four underlying dimensions of guilt construct, namely, fear of punishment, care for others, God consciousness and forgiveness. The present study findings, though exploratory, hope to further our understanding of moral emotions in a broader context. Shame and guilt had been identified as the motivational forces of moral behaviour. Although shame has been recognized as maladpative in Western countries this is not true for the Asian population especially for Malaysians Muslim. Accordingly, instruments such as the MMEI can help to identify the dimension of adaptive shame and guilt and can be useful toward inculcating the adaptive shame and guilt among youth and other.

\section{Limitation and Study Forward}

Several limitations should be noted when interpreting the results of this study. The data was collected among Muslim youth in Malaysia only. Therefore, this limits the generalizability of the findings in several ways. First, since the researcher opted to 
concentrate on Malaysian Muslim youth only, the results cannot be generalized to the general population especially to other Muslims populations from different countries. A larger sample size may provide more conclusive data in future studies.

This study also has limitations in the use of a self-report questionnaire. Although the measure used in this study demonstrated adequate reliability and validity, the self-report questionnaire assesses what participants believe to be true or what they are willing to communicate. The exclusive use of a self-report measures to assess moral emotions could lead to response bias, particularly given the context and timing in which the respondents were asked to rate their level of emotions. Incorporating an interview in future studies may add a richer dataset to the self-report measures and accords better insight into the youths' moral emotions. Sometimes the reliance on self-reports alone may represent the desired rather than the real experience and feeling (Breslavs, 2013).

It is acknowledged that there are limitations inherent in cross-sectional research as well as data collection. Therefore, this study should be regarded as exploratory yet highly promising. Future studies using longitudinal design will be useful to gain a deeper understanding of moral emotion.

\section{Corresponding Author}

Abdul Rashid bin Abdul Aziz

Faculty of Leadership and Management Universiti Sains Islam Malaysia, 71800, Bandar Baru

Nilai, Negeri Sembilan, Malaysia

Email: rashid@usim.edu.my

\section{References}

Aknouche, N., \& Noor, N. M. (2014). The Primacy of the Self in Shame: Can Shame Be Benevolent? American International Journal of Social Science, 3(1), 59-79.

Breslavs, G. M. (2013). Moral emotions, conscience, and cognitive dissonance. Psychology in Russia: State of the Art, 6, 65-72.

Cohen, L., Manion, L., \& Morrison, K. (2000). Research Methods in Education. $5^{\text {th }}$ Edition. London: Routledge Falmer. http://dx.doi.org/10.4324/9780203224342

Dempsey, H. L. (2017). A Comparison of the Social-Adaptive Perspective and Functionalist Perspective on Guilt and Shame. Behavioral Sciences, 7(83), 1-19.

De Vellis, R. (1991). Scale development: Theory and Applications. Newbury Park, California: Sage Publication.

Ferguson, T. J., Stegge, H., Eyre, H. L., Vollmer, R., \& Ashbaker, M. (2000). Context effects and the (mal) adaptive nature of guilt and shame in children. Genetic, Social, and General Psychology Monographs, 126, 319-345.

Haidt, J. (2003). The moral emotions. In R. J. Davidson, K. R. Scherer, \& H. H. Goldsmith (Eds.), Handbook of affective sciences. Oxford: Oxford University Press. 852-870.

Hair, J. F., Black, W. C., Babin, B. R., Anderson, R. E., \& Tantham, R. L. (2006). Multivariate Data Analysis. $6^{\text {th }}$ Ed. New Jersey: prentice Hall.

Hassan, S. A., \& Bakar, K. A. (2009). Exploratory Factor Analysis versus Confirmatory Factor Analysis. In Rahman, F. A., Piee@shafiee, F., \& Elias, H. (Eds.) Teachers' learning, curriculum innovations and knowledge applications. 128-137. Serdang: UPM Press.

Hassan, S. A., Abdullah, A. S., Ishak, N., \& Langgulung, H. (2008). Measuring the unmeasurable: Maternal piety scales. Pertanika Journal of Social Sciences \& Humanities, 6(1), 95-105. 
Hassan, S. A. (2006). Maternal quality time, children's emotional intelligence and their academic performance: A structural equation modeling analysis [Unpublished Doctoral Dissertation], International Islamic University of Malaysia.

Hatcher, L. A. (1994). Step-by-Step Approach to Using the SAS ${ }^{\circledR}$ System for Factor Analysis and Structural Equation Modeling. Cary, N.C: SAS Institutte, Inc.

Herijanto, H. (2017). Tawhidi Principle in the Perspective of Men to Perform Social Deeds. International Journal of Humanities and Social Science, 7(3), 61-68.

Hopkins, K. D. (1998). Educational and Psychological Measurement and Evaluation. (8 ${ }^{\text {th }}$ Edition). Needham Heights, MA: Allyn and Bacon.

Jumahat, T., \& Abdullah, N. F. (2014). Perbandingan Konsep Kecerdasan Spiritual dari Perspektif Islam dan Barat: Satu Penilaian Semula. Proceeding of the International Conference on Arabic Studies and Islamic Civilization, Kuala Lumpur.

Kline, P. (1994). An Easy Guide to Factor Analysis. London: Routledge.

Konting, M. M. (2000). Kaedah Penyelidikan Pendidikan. Kuala Lumpur: Dewan Bahasa dan Pustaka.

Lantos, E., \& Rezmovic, V. A. (1981). confirmatory factor analysis approach to construct validation. Educational and Psychological Measurement, 41(1), 61-72.

Liu, V. (2015). The Incorporation of Spirituality in to Counselling Within a Holistic Paradigm in a Secular World. [Unpublished Master thesis]. Vancouver: City University of Seattle, Canada site.

Malaysia Crime Statistics Report. (2020). Department of Statistics. Kuala Lumpur: Malaysia.

Mohamad, O. (2001). Penulisan tesis dalam bidang Sains Sosial terapan. Serdang: Universiti Putra Malaysia.

Othman, N. (2011). Exploring the Ummatic Personality Dimensions from the Psycho-spiritual Paradigm. International Journal of Psychological Studies, 3(2), 37-47.

Rahman, Z. A., Stapa, Z., Omar, M. N., Long, A. S., Badaruddin, F., Awang, J., Ibrahim, M., Ismail, I., Sarnon @ Kusenin, N. H., Hoesni, S. M., Zain, A. A. M., Kadir, F. A. A., \& Siren, N. (2011). Faktor-faktor dalaman penyebab berlakunya jenayah rogol menurut ulama Islam di Malaysia. Prosiding Nadwah Ulama Nusantara (NUN) IV:Ulama Pemacu Transformasi Negara.Malaysia.

Scheff, T. (2014). The Ubiquity of Hidden Shame in Modernity. Cultural Sociology, 8(2), 129 141.

Stevens, J. (2002). Applied Multivariate Statistics for The Social Sciences. New Jersey: Lawrence Erlbaum Associates, Publishers.

Stevens, J. (1996). Applied Multivariate Statistics for The Social Sciences. New Jersey: Lawrence Erlbaum Associates, Publishers.

Syed, J., \& Ali, F. (2006). Emotion regulation and Muslim women at work. In D. Hurst (Ed). Consequentiality Volume II: Mythology, Theology and Ontology. Florida: Talahassee, 189-210.

Tangney, J. P., \& Tracy, J. (2011). Self-conscious emotions. In Mark E. Leary \& June P. Tangney (Eds.), Handbook of Self and Identity (446-480). New York: Guilford Press.

Tangney, J. P., Stuewig, J., \& Mashek, D. J. (2007). Moral emotions and moral behavior. Annual Review Psychology, 58, 345-72.

Tangney J. P., Wagner P. E., Gramzow R. (1989). The Test of Self-Conscious Affect (TOSCA). Fairfax, VA: George Mason University.

Tibbetts, S. G. (1997). Shame and Rational Choice in Offending Decisions. Criminal Justice and Behavior, 24(2), 234-255. https://doi.org/10.1177/0093854897024002006 
Thompson, B. (2004). Exploratory and Confirmatory Factor Analysis: Understanding Concepts and Applications. Washington, DC: American Psychological Association.

Thorndike, R. (1997). Measurement and Evaluation in Psychology and Education. $6^{\text {th }}$ Ed. New Jersey: Prentice Hall.

Yasien, M. (2009). Psychology of Personality: Islamic Perspectives. Kuala Lumpur: Cengage Learning Asia. 